Archives of Agriculture and Environmental Science

\title{
Effect of biofertilizer and weeding regimes on yield performance of bush bean (Phaseolus vulgaris L.)
}

\author{
F.M.J. Uddin* ID , Nazmul Hasan, Md. Rashedur Rahman and Md. Romij Uddin \\ Department of Agronomy, Bangladesh Agricultural University, Mymensingh - 2202, BANGLADESH \\ "Corresponding author's E-mail: drjamil@bau.edu.bd
}

\section{ARTICLE HISTORY}

Received: 12 June 2018

Revised received: 08 August 2018

Accepted: 18 August 2018

\section{Keywords}

Bush bean (Phaseolus vulgaris L.)

Biofertilizer

Weeding regimes

Yield

\begin{abstract}
In order to assess the effect of biofertilizer and weeding regimes and their interaction on the performance of bush bean (Phaseolus vulgaris L.), a field experiment was conducted at the Agronomy Field Laboratory, Bangladesh Agricultural University, Mymensingh following randomize complete block design (RCBD) with three replications during winter season, in 2017. The experiment consisted of five treatments of biofertilizer $\left(B_{0}=\right.$ no biofertilizer, $B_{1}=1.0$ Kg biofertilizer ha ${ }^{-1}, B_{2}=1.5 \mathrm{Kg}$ biofertilizer ha ${ }^{-1}, B_{3}=2.0 \mathrm{Kg}$ biofertilizer ha ${ }^{-1}, B_{4}=2.5 \mathrm{Kg}$ biofertilizer $\mathrm{ha}^{-1}$ ) and four level of weeding $\mathrm{W}_{0}=$ No weeding, $\mathrm{W}_{1}=$ One weeding at $15 \mathrm{DAS}, \mathrm{W}_{2}=$ Two weeding at 15 DAS and 30 DAS, $W_{3}=$ Three weeding at 15 DAS, 30 DAS and 45 DAS. Yield contributing characters were significantly influenced by biofertilizer and weeding regimes. In case of attributes affected by yield factor for biofertilizer the highest plant height, weight of seed plant ${ }^{-1}$, grain and stover yield in $1.5 \mathrm{Kg}$ biofertilizer ha ${ }^{-1}$, number of seed plant $^{-1}$ in $1.0 \mathrm{Kg}$ biofertilizer ha ${ }^{-1}$, weight of 1000 seeds in no biofertilizer and harvest index in $2.0 \mathrm{Kg}$ biofertilizer ha ${ }^{-1}$ treatments were observed. Considering yield attributes against weeding regimes, the highest plant height, grain yield, stover yield and harvest index in three weeding, weight of seeds plant ${ }^{-1}$ and weight of 1000 seeds in two weeding were found. In case of interaction effect highest plant height in $B_{2} W_{3}$, weight of seeds plant ${ }^{-1}$ in $B_{4} W_{2}$, weight of 1000 seeds in $B_{1} W_{3}$, grain yield in $B_{3} W_{3}$, stover yield in $B_{3} W_{3}$ and harvest index in $B_{0} W_{3}$ were observed. The results obtained in experiment indicate that there is ample scope to increase the yield of bush bean by applying proper dose of biofertilizer and management of weeding regimes.
\end{abstract}

(c)2018 Agriculture and Environmental Science Academy

Citation of this article: Uddin, F.M.J., Hasan, N., Rahman, M.R. and Uddin, M.R. (2018). Effect of biofertilizer and weeding regimes on yield performance of bush bean (Phaseolus vulgaris L.). Archives of Agriculture and Environmental Science, 3(3): 226-231, https://dx.doi.org/10.26832/24566632.2018.030303

\section{INTRODUCTION}

Bush bean or French bean (Phaseolus vulgaris L.) is an important vegetable crop belonging to the family Leguminosae and subfamily Papiolionaceae, is known as 'Farashi Seem' (Rashid, 1993) or Jhar sheem (BARI, 2014) in Bangladesh. The cultivation of Bush bean is very popular in Chittagong, Sylhet, North Bengal, Hill tracts and also many other places of Bangladesh. Now days, it is considered as one of the most important exporting vegetables of Bangladesh to earn foreign currency and is being exported by Horticultural Export Foundation, Dhaka, Bangladesh. The average yield of Bush bean is very low in Bangladesh due to various reasons, where biofertilizer and weeding are considered as one of the important factors. In Bangladesh, dry bean is produced in 62870 ha of land, production is 51320 tones and average yield is $816.3 \mathrm{Kg} \mathrm{ha}^{-1}$ (FAO, 2014). Its edible pods supply protein, carbohydrate, fat, fibre, thiamin, riboflavin, $\mathrm{Ca}$ and Fe (Shanmugavelu, 1989) and the seed contains significant amount of thiamin, niacin, folic acid (Rashid, 1993). Bush bean shows high yield potential, but unlike other leguminous crops it does not modulate with the native rhizobia (Ali and Kushwaha, 1987). Therefore, requirement of nitrogenous fertilizers for the 
crop is of prime importance.

Bush bean related research works are very few in our country but in other crop like mungbean we can see biofertilizer effect. Seed inoculation with effective Bradyrhizobium can play a vital role in the formation of nodules to fix atmospheric nitrogen by symbiotic process in the root system of legume crops making the nutrient available to the plants (Bhuiya et al., 1984; Chouwdhury et al., 2000; Anjum et al., 2006; Mia and Shamsuddin, 2010; Mulas et al., 2011; Malik et al., 2014; Mmbaga et al., 2014). In Bangladesh, inoculation with Bradyrhizobium increased $57 \%$ effective nodules, $77 \%$ dry matter production, $64 \%$ grain yield and $40 \%$ hay yield as compared with uninoculated mungbean cultivation (Chanda et al., 1991). Uddin et al. (2013) reported that mungbean produced higher yield with response to different doses of phosphorus and planting date when seeds were inoculated with rhizobium at the time of sowing. The yield contributing characters and yield of Bush bean varieties were increased/decreased in compare to very early or late sowing condition during Rabi season (Uddin et al., 2017).

A research in China (Hussein and Joo, 2011) illustrates the benefits of using effective microorganisms (EM) either fungal or bacterial ones for the improvement of the Chinese cabbage growth and crop yield, by increasing and enhancing the microbial density in soil significantly. An evaluation of the efficiency of EM cultures for improving biological nitrogen fixation of uninoculated tropical food legumes, namely bush beans or vegetable beans (Phaseolus vulgaris), was the basis of this investigation. The legume was selected on the basis of their nodulation characteristics; bush bean is a species with low nitrogen-fixation abilities (Lawn and Ahn, 1985; Graham, 1981).

Weed is an important factor responsible for low yield of crops (Islam et al., 2006). Weed is very much ecofriendly with the growth and development of mungbean and yield losses due to weed in mungbean ranges from 27 to 100\% (Madrid and Vega, 1971; BARI, 1985). Therefore, weed control is very essential for mungbean cultivation. In Bangladesh, farmers do not interest to control weed in mungbean; possibly, it may be one of the causes for low yield of mungbean in the country. The time of weeding has an important effort on the growth and yield of mungbean. Weeding at wrong time and wrong stage of the crop growth may not be beneficial. Not much research work so far was done on the effect of bio-fertilizer and weeding on bushbean growth and yield. In this context, present study was undertaken to investigate the proper dose of rhizobium for yield performance of bush bean, to investigate the effect of weeding regimes on yield attributes of bush bean (Phaseolus vulgaris L.) and to evaluate the interaction effect of rhizobium and weeding regime on yield performance of bush bean.

\section{MATERIALS AND METHODS}

\section{Experimental site}

The experiment was conducted at the Agronomy Field Laboratory which is belongs to the Old Brahmaputra Floodplain (AEZ-
9) where non-calcareous dark-gray, floodplain soils are generally pre dominant. The land was medium high and the soil was silty loam well drained with low general fertility level and organic matter content (1.19\%) with neutral in nature ( $\mathrm{pH} 6.82)$.

\section{Treatments and experimental deign}

The experiment consisted of two factors viz. (A) Biofertilizer (B) Weeding regimes. There were five levels of biofertilizer as follows: $B_{0}=$ Control (no biofertilizer), $B_{1}=1.0 \mathrm{Kg}$ biofertilizer $\mathrm{ha}^{-1}$ seed treatment, $\mathrm{B}_{2}=1.5 \mathrm{Kg}$ biofertilizer ha ${ }^{-1}$ seed treatment, $\mathrm{B}_{3}=2.0 \mathrm{Kg}$ biofertilizer ha ${ }^{-1}$ seed treatment and $\mathrm{B}_{4}=2.5$ $\mathrm{Kg}$ biofertilizer ha ${ }^{-1}$ seed treatment. The following four levels of weeding were used: $W_{0}=$ No hand weeding, $W_{1}=$ One hand weeding at 15 Days after sowing (DAS), $W_{2}=$ Two hand weeding at 15 and 30 Days after sowing (DAS) and $W_{3}=$ Three hand weeding at 15,30 and 45 Days after sowing (DAS). The experiment was laid out in a Randomized Complete Block Design with three replications. Each replication had 20 unit plots. The unit of plot size was $5 \mathrm{~m}^{2}(2.5 \mathrm{~m} \times 2 \mathrm{~m})$. The blocks and unit plots were separated by $1 \mathrm{~m}$ and $0.75 \mathrm{~m}$ spacing, respectively. The Bradyrhizobium inoculums strains and seeds of bushbean variety viz. BARI jharsheem-2 used in present study were collected from Bangladesh Agricultural Research Institute (BARI), Jaydebpur, Gazipur. Only one Bradtrhizobium strain was used in this experiment.

\section{Crop husbandry}

The field was prepared by three times ploughing and cross ploughing followed by laddering. The weeds and stubble were removed from each plot and the field was leveled properly before sowing. Layout of the experiment was done according to treatment combination. After layout the land was fertilized with $75 \mathrm{Kg}$ and $40 \mathrm{Kg} \mathrm{ha}^{-1}$ of triple superphosphate and muriate of potash, respectively. All fertilizers were applied the time of final land preparation. The fertilizers were applied by broadcasting and were mixed with soil thoroughly. The quantity of seed required $35 \mathrm{~g}$ for each plot was weighed on the basis of experiment specification (five levels of biofertilizer viz., 0, 1.0, 1.5, 2.0 and $2.5 \mathrm{Kg}^{-1}$ ), considering $90 \%$ purity, $80 \%$ germination, $20 \%$ safety allowance. Then it was kept in polythene bags. Bradyrhizobium broth cultures were mixed thoroughly with seed per treatment with molasses and were placed in cool dry place. The seeds were sown in line to line distance of $30 \mathrm{~cm}$ and plant to plant distance $15 \mathrm{~cm}$ and were covered with soil. Seeds were sown at $70 \mathrm{Kg} \mathrm{ha}{ }^{-1}$. Weeding was given in the plots as per treatment specification. Thinning was done to remove diseased plants. Hand irrigation was given in some plots where soils were dry. Cutworm was successfully controlled by application of Savin 50 wp $2 \mathrm{Kg} \mathrm{ha}^{-1}$ rate mixing with rice husk and molasses.

\section{Crop harvesting and data collection}

The crop was harvested at 118 DAS from all plots. Before harvesting five plants were selected randomly from each plot and were uprooted for data recording. The rest of the plants were harvested plot $^{-1}$ wise and were bundled separated, tagged 
and brought to the threshing floor of Agronomy Field Laboratory. The crop bundles were sun dried for five days by placing them on the open threshing floor. Seeds were separated from the plants by beating the bundles with bamboo sticks. The collected seeds were dried in the sun for reducing the moisture content at a constant level. The dried seeds and stover were cleaned and weighed.

Yield data was recorded from five randomly selected plants from each plot on the following parameters: Plant height at harvest $(\mathrm{cm})$, number of pods plant ${ }^{-1}$ length of pod $(\mathrm{cm})$, number of seeds pod $^{-1,}$ number of seeds plant ${ }^{-1}$ weight of seeds plant ${ }^{-1}$ (g), grain yield $\left(\mathrm{Kg} \mathrm{ha}^{-1}\right)$, stover yield $\left(\mathrm{Kg} \mathrm{ha}^{-1}\right)$, weight of 1000 seeds and harvest index (\%). Harvest Index was calculated with the following formula:

Harvest index $=$ Grain yield $/($ Grain yield + Stover yield $) \times 100$

\section{Statistical analysis of data}

The collected data were first checked for normality distribution and subjected to two-way analysis of variance (two-way ANOVA) followed by Duncan's multiple range tests (Gomez and Gomez, 1984) to evaluate the mean difference among the treatments with Computer package program MSTAT.

\section{RESULTS AND DISCUSSION}

Effect of biofertilizer on yield contributing characters and yield of Bush bean

The effect of biofertilizer on plant height, number of pods plant ${ }^{1}$, number of seeds plant ${ }^{-1}$, weight of seeds plant ${ }^{-1}$, weight of 1000 seeds, grain and stover yield was significant. The highest weight of 1000 seeds (237.22 g) from $0 \mathrm{Kg}$ biofertilizer ha ${ }^{-1}$, plant height $(34.39 \mathrm{~cm})$, number of pods plant ${ }^{-1}(6.93)$, number of seeds plant ${ }^{-1}(21.86)$ and weight of seeds plant ${ }^{-1}(3.6 \mathrm{~g})$ from $1.5 \mathrm{Kg}$ biofertilizer ha- ${ }^{-1}$, grain yield $\left(747.73 \mathrm{Kg} \mathrm{ha}^{-1}\right)$ and stover yield $\left(1177.13 \mathrm{Kg} \mathrm{ha}^{-1}\right.$ ) were obtained from $2.5 \mathrm{Kg}$ biofertilizer $\mathrm{ha}^{-1}$ (Table 1). The lowest plant height $(25.68 \mathrm{~cm})$, number of pods plant ${ }^{-1}(4.98)$,weight of seeds plant ${ }^{-1}(2.8 \mathrm{~g})$, grain yield (544.99 $\mathrm{Kg} \mathrm{ha}^{-1}$ ), stover yield (859.06 $\mathrm{Kg} \mathrm{ha}^{-1}$ ) was observed from $0 \mathrm{Kg}$ biofertilizer ha ${ }^{-1}$ treatment, and number of seeds plant $^{-1}$ (13.39) and weight of 1000 seeds (222.93 g) were observed from $2 \mathrm{Kg}$ biofertilizer ha ${ }^{-1}$ treatment (Table 1). The effect of biofertilizer on length of pod, number of seeds pod ${ }^{-1}$, and harvest index was not significant. Numerically, the highest length of pod $(9.57 \mathrm{~cm})$ from $1.5 \mathrm{Kg}$ biofertilizer ha ${ }^{-1}$, number of seeds pod $^{-1}$ (4.40) from $1 \mathrm{Kg}$ biofertilizer ha- ${ }^{-1}$ and harvest index (39.19\%) was obtained from $2.0 \mathrm{Kg}$ biofertilizer ha- ${ }^{-1}$ treatment was observed. The lowest number of seeds $\operatorname{pod}^{-1}$ (4.13) from 0 and $2 \mathrm{Kg}$ biofertilizer $\mathrm{ha}^{-1}$, harvest index (38.21\%) from $1.5 \mathrm{Kg}$ biofertilizer ha ${ }^{-1}$, length of pod $(8.82 \mathrm{~cm})$ was observed from $2 \mathrm{~kg}$ biofertilizer ha ${ }^{-1}$ dose (Table 1). In this connection, Islam et al. (2006) reported that most of the plant growth parameters in mungbean such as number of branches plant ${ }^{-1}$, number of leaves plant $^{-1}$, number of effective nodules plant ${ }^{-1}$, number of noneffective nodules plant ${ }^{-1}$, root dry weight plant $^{-1}$, nodule dry weight plant ${ }^{-1}$ was the height due to the application of bioferti- lizer (Bradyrhizobium). Gicharu et al. (2013) also found that the number of nodules, total plant dry weight among the bush bean cultivars differed statistically at $P \leq 0.05$ due to response to rhizobia strain used both in greenhouse and field experiment. Pramanik et al. (2014) found the highest plant height $(58.83 \mathrm{~cm})$ was obtained at 60DAS from $4 \mathrm{Kg}$ biofertilizer ha ${ }^{-1}$ and the highest dry weight plant ${ }^{-1}(17.78 \mathrm{~g})$ at 60DAS was produced from 2 $\mathrm{kg}$ biofertilizer ha ${ }^{-1}$ in summer mungbean.

Effect of weeding regimes on yield contributing characters and yield of Bush bean

The effect of weeding regimes on plant height, number of pods plant $^{-1}$, weight of seeds plant ${ }^{-1}$, weight of 1000 seeds and grain and stover yield was significant. The highest plant height (34.80 $\mathrm{cm})$, stover yield $\left(1196.80 \mathrm{Kg} \mathrm{ha}^{-1}\right)$, grain yield $\left(770.59 \mathrm{Kg} \mathrm{ha}^{-1}\right)$ were obtained from three weeding and number of pod plant ${ }^{-1}$ (6.36), weight of seeds plant ${ }^{-1}(3.61 \mathrm{~g})$ and weight of 1000 seeds $(232.33 \mathrm{~g})$ were obtained from two weeding (Table 1). The lowest plant height $(27.48 \mathrm{~cm})$, number of pod plant ${ }^{-1}(5.19)$, weight of 1000 seeds (226.05 g), grain yield (493.15 Kg ha-1), stover yield (799.35 Kg ha-1) was observed from no weeding and the weight of seeds plant ${ }^{-1}(2.84 \mathrm{~g})$ were observed from three weeding treatment (Table 1 ). The effect of weeding regimes on length of pod, number of seeds pod $^{-1}$, number of seeds plant $^{-1}$ and harvest index was not significant. Numerically, the highest length of pod $(9.46 \mathrm{~cm})$, number of seeds $\operatorname{pod}^{-1}(4.43)$ from one weeding, number of seeds plant ${ }^{-1}$ (21.21) from two weeding, harvest index (39.24\%) from three weeding were observed (Table 1). The lowest length of pod $(8.85 \mathrm{~cm})$, number of seeds $\operatorname{pod}^{-1}(4.05)$ and number of seeds plant ${ }^{-1}$ (16.00) and harvest index (38.29\%) were observed from no weeding (Table 1). Esmaeilzadeh and Aminpanah (2015) carried out an experiment to evaluate the effect of planting date and spatial pattern on common bean yield under weed-free and weed-infested conditions and found that due to weed competition, seed and pod yields were reduced by $11.6 \%$ and $7.6 \%$, respectively. Pramanik et al. (2015) reported that the entire yield contributing characters of mungbean responded linearly with increasing the number of weeding treatment. Among the weeding regimes, the highest number of branches plant ${ }^{-1}$ (2.68), number of pods plant ${ }^{-1}(20.14)$, pod length $(5.44 \mathrm{~cm})$, number of seeds $\operatorname{pod}^{-1}$ (16.30), seed weight plant ${ }^{-1}$ (24.63 g), 1000-seed weight $(39.35 \mathrm{~g})$, seed yield $\left(2.00 \mathrm{t} \mathrm{ha}^{-1}\right)$, stover yield $\left(2.99 \mathrm{t} \mathrm{ha}^{-1}\right)$, biological yield $\left(4.99 \mathrm{t} \mathrm{ha}^{-1}\right.$ ) were obtained from three time weeding plots and two times weeding produced the highest harvest index (42.61\%).

Interaction effect of biofertilizer and weeding regimes The effect of interaction on weight of seeds plant ${ }^{-1}$, length of pod and grain yield was significant. The highest weight of seeds plant $^{-1}(5.16 \mathrm{~g})$ from $\mathrm{B}_{4} \mathrm{~W}_{2}\left(2.5 \mathrm{Kg} \mathrm{ha}^{-1}\right.$ biofertilizer and two weeding), length of pod $\left(10.27 \mathrm{~cm}\right.$ ) was obtained from $B_{0} W_{1}$ (no biofertilizer and no weeding) treatment and grain yield (886.17 $\mathrm{Kg} \mathrm{ha}^{-1}$ ) was obtained from $\mathrm{B}_{3} \mathrm{~W}_{3}\left(2 \mathrm{Kg}\right.$ biofertilizer ha ${ }^{-1}$ and three weeding) were obtained. The lowest weight of seeds plant 
${ }^{-1}(1.61 \mathrm{~g})$ and length of pod $(7.60 \mathrm{~cm})$ were observed from $B_{3} W_{0}$ ( $2 \mathrm{Kg}$ biofertilizer $\mathrm{ha}^{-1}$ and no weeding) treatment and grain yield $\left(388.37 \mathrm{Kg} \mathrm{ha}^{-1}\right.$ ) from $\mathrm{B}_{0} \mathrm{~W}_{0}$ (no biofertilizer and no weeding) treatment was observed (Table 2). The effect of interaction on plant height, number of pods plant ${ }^{-1}$, number of seeds pod ${ }^{-1}$, and number of seeds plant ${ }^{-1}$ and weight of 1000 seeds was not significant. Numerically, the highest plant height $(38.47 \mathrm{~cm})$ from $\mathrm{B}_{2} \mathrm{~W}_{3}$ (1.5 Kg biofertilizer ha ${ }^{-1}$ and three weeding) treatment, number of pod plant ${ }^{-1}$ (7.80) were obtained from $B_{4} W_{2}$ treatment, number of seeds pod $^{-1}$ (4.93) was obtained from $B_{1} W_{1}$, number of seeds plant ${ }^{-1}$ (29.72) was obtained from $B_{4} W_{2}$, weight of 1000 seeds ( $240.27 \mathrm{~g}$ ) was obtained from $B_{1} W_{3}(1 \mathrm{Kg}$ biofertilizer ha ${ }^{-1}$ and three weeding) treatment (Table 2). On the other hand, the lowest plant height $(21.09 \mathrm{~cm})$ and number of pods plant ${ }^{-1}$ (4.23) from $B_{0} W_{0}$ treatment, number of seeds pod ${ }^{-1}$ (3.00), number of seeds plant ${ }^{-1}$ (4.89) and weight of 1000 seeds $\left(216.87 \mathrm{~g}\right.$ ) were observed from $\mathrm{B}_{3} \mathrm{~W}_{0}\left(2 \mathrm{Kg}\right.$ biofertilizer ha ${ }^{-1}$ and no weeding) treatment (Table 2).

Table 1. Effect of biofertilizer and weeding regimes on yield and yield attributes of bushbean.

\begin{tabular}{|c|c|c|c|c|c|c|c|c|c|c|}
\hline Biofertilizer & $\begin{array}{c}\text { Plant } \\
\text { height at } \\
\text { harvest } \\
(\mathrm{cm})\end{array}$ & $\begin{array}{l}\text { Number } \\
\text { of pods } \\
\text { plant }^{-1}\end{array}$ & $\begin{array}{l}\text { Length } \\
\text { of pods } \\
(\mathrm{cm})\end{array}$ & $\begin{array}{l}\text { No of } \\
\text { seeds } \\
\text { pod }^{-1}\end{array}$ & $\begin{array}{l}\text { No. of } \\
\text { seeds } \\
\text { plant }^{-1}\end{array}$ & $\begin{array}{l}\text { Weight of } \\
\text { seed } \\
\text { plant }^{-1}(g)\end{array}$ & $\begin{array}{c}\text { Weight of } \\
1000 \\
\text { seeds (g) }\end{array}$ & $\begin{array}{l}\text { Grain } \\
\text { yield } \\
\text { (Kg/ha) }\end{array}$ & $\begin{array}{l}\text { Stover } \\
\text { yield } \\
\text { (Kg/ha) }\end{array}$ & $\begin{array}{l}\text { Harvest } \\
\text { index (\%) }\end{array}$ \\
\hline $\mathrm{B}_{0}$ & $25.68 c$ & $4.98 c$ & 9.21 & 4.13 & $17.05 b c$ & $2.8 \mathrm{c}$ & $237.22 a$ & $544.99 d$ & $859.06 d$ & 38.67 \\
\hline $\mathrm{B}_{1}$ & $29.48 b$ & $5.18 b c$ & 9.36 & 4.40 & $20.11 a b$ & $3.26 \mathrm{~b}$ & $233.59 b$ & $607.73 c$ & $949.69 c$ & 38.97 \\
\hline $\mathrm{B}_{2}$ & $34.39 a$ & $6.93 a$ & 9.57 & 4.18 & $21.86 a$ & $3.6 a$ & $230.67 b$ & $646.23 b$ & $1048.06 \mathrm{~b}$ & 38.21 \\
\hline $\mathrm{B}_{3}$ & $34.19 a$ & $5.31 b c$ & 8.82 & 4.13 & $13.39 c$ & $2.904 c$ & $222.93 c$ & $734.82 a$ & $1139.63 a$ & 39.19 \\
\hline $\mathrm{B}_{4}$ & $33.93 a$ & $5.91 \mathrm{~b}$ & 8.95 & 4.30 & 19.63ab & $3.414 a b$ & $223.30 c$ & 747.73a & $1177.13 a$ & 39.02 \\
\hline CV (\%) & 6.54 & 5.45 & 11.54 & 7.27 & 12.25 & 6.22 & 3.02 & 5.69 & 7.45 & 8.85 \\
\hline $\begin{array}{l}\text { Level of sig. } \\
\text { Weeding } \\
\text { regimes }\end{array}$ & $* *$ & $* *$ & NS & NS & $* *$ & $* *$ & $* *$ & $* *$ & $* *$ & NS \\
\hline $\mathrm{W}_{0}$ & $27.48 d$ & $5.19 \mathrm{~b}$ & 8.85 & 4.05 & 16.00 & $2.98 \mathrm{~b}$ & $226.05 c$ & $493.15 d$ & $799.35 d$ & 38.29 \\
\hline$W_{1}$ & $31.16 \mathrm{c}$ & $5.75 a b$ & 9.46 & 4.43 & 18.71 & $3.43 a$ & $229.11 b$ & $645.60 c$ & $1020.05 c$ & 38.79 \\
\hline$W_{2}$ & $32.70 \mathrm{~b}$ & $6.36 a$ & 9.33 & 4.36 & 21.21 & $3.61 a$ & $232.33 a$ & $715.86 b$ & $1122.65 b$ & 38.93 \\
\hline $\mathrm{W}_{3}$ & $34.80 a$ & $5.34 b$ & 9.07 & 4.08 & 17.70 & $2.84 \mathrm{~b}$ & $230.68 \mathrm{ab}$ & $770.59 a$ & $1196.80 a$ & 39.24 \\
\hline CV (\%) & 6.54 & 5.45 & 11.54 & 7.27 & 12.25 & 6.22 & 3.02 & 5.69 & 7.45 & 8.85 \\
\hline Level of sig. & $* *$ & $* *$ & NS & NS & NS & $* *$ & $* *$ & $* *$ & $* *$ & NS \\
\hline
\end{tabular}

In a column the figure bearing same letter(s) or without letter is identical and those having dissimilar letter differed significantly. ${ }^{*}=$ Significant at $5 \%$ level, ${ }^{* *}=$ Significant at $1 \%$ level, NS= Non significant; $B_{0}=$ no biofertilizer, $B_{1}=1.0 \mathrm{~kg} \mathrm{ha}^{-1}$ biofertilizer, $\mathrm{B}_{2}=1.5 \mathrm{~kg}^{-1} \mathrm{biofertilizer} \mathrm{B}_{3}=2.0 \mathrm{~kg}$ ha ${ }^{-1}$ biofertilizer, $B_{4}=2.5 \mathrm{~kg} \mathrm{ha}^{-1}$ biofertilizer; $W_{0}=$ No weeding, $W_{1}=$ One weeding at $15 \mathrm{DAS}, \mathrm{W}_{2}=$ Two weeding at 15 DAS and 30 DAS, $W_{3}=$ Three weeding at 15 DAS, 30 DAS and 45DAS.

Table 2. Interaction effects of biofertilizer and weeding regimes on yield and yield attributes of bushbean.

\begin{tabular}{|c|c|c|c|c|c|c|c|c|c|c|}
\hline $\begin{array}{l}\text { Treatment } \\
\text { Combination } \\
\text { (Biofertilizerx } \\
\text { Weeding } \\
\text { regimes) }\end{array}$ & $\begin{array}{l}\text { Plant } \\
\text { height } \\
\text { at } \\
\text { harvest } \\
\text { (cm) }\end{array}$ & $\begin{array}{l}\text { Number } \\
\text { of pods } \\
\text { plant }^{-1}\end{array}$ & $\begin{array}{l}\text { Length } \\
\text { of pods } \\
(\mathrm{cm})\end{array}$ & $\begin{array}{l}\text { No. of } \\
\text { seeds } \\
\text { pod }^{-1}\end{array}$ & $\begin{array}{l}\text { No. of } \\
\text { seeds } \\
\text { plant }^{-1}\end{array}$ & $\begin{array}{l}\text { Weight } \\
\text { of seed } \\
\text { plant }^{-1} \\
\text { (g) }\end{array}$ & $\begin{array}{l}\text { Weight of } \\
1000 \\
\text { seeds (g) }\end{array}$ & $\begin{array}{c}\text { Grain } \\
\text { yield (Kg/ } \\
\text { ha) }\end{array}$ & $\begin{array}{l}\text { Stover } \\
\text { yield } \\
\text { (Kg/ha) }\end{array}$ & $\begin{array}{l}\text { Harvest } \\
\text { index (\%) }\end{array}$ \\
\hline $\mathrm{B}_{0} \times \mathrm{W}_{0}$ & 21.09 & 4.23 & $8.63 \mathrm{cde}$ & 4.33 & 17.62 & $3.32 d-g$ & 233.07 & $388.37 \mid$ & 670.00 & 36.76 \\
\hline $\mathrm{B}_{0} \times \mathrm{W}_{1}$ & 26.78 & 4.40 & $10.27 a$ & 4.60 & 17.46 & $3.25 \mathrm{~d}-\mathrm{g}$ & 238.53 & $539.17 \mathrm{ij}$ & 837.25 & 39.10 \\
\hline $\mathrm{B}_{0} \times \mathrm{W}_{2}$ & 25.98 & 5.87 & $9.20 a-d$ & 3.53 & 16.17 & $2.46 i$ & 240.10 & $623.33 \mathrm{fg}$ & 985.00 & 38.75 \\
\hline $\mathrm{B}_{0} \times \mathrm{W}_{3}$ & 28.87 & 5.40 & $8.73 b-e$ & 4.07 & 16.93 & 2.64hi & 237.17 & $629.10 \mathrm{fg}$ & 944.00 & 40.08 \\
\hline $\mathrm{B}_{1} \times \mathrm{W}_{1}$ & 25.98 & 5.80 & $9.17 a-d$ & 4.93 & 19.52 & $3.28 \mathrm{~d}-\mathrm{g}$ & 230.30 & $485.87 \mathrm{k}$ & 798.75 & 37.86 \\
\hline $\mathrm{B}_{1} \times \mathrm{W}_{2}$ & 28.85 & 5.20 & $9.80 \mathrm{abc}$ & 4.00 & 18.42 & 2.82ghi & 232.20 & $596.67 \mathrm{gh}$ & 917.50 & 39.42 \\
\hline $\mathrm{B}_{1} \times \mathrm{W}_{3}$ & 31.60 & 5.20 & $8.97 a-d$ & 4.13 & 21.57 & $3.52 \mathrm{cde}$ & 240.27 & $645.00 f$ & 1005.00 & 39.09 \\
\hline $\mathrm{B}_{1} \times \mathrm{W}_{4}$ & 31.50 & 4.53 & $9.50 a-d$ & 4.53 & 20.94 & $3.41 c-f$ & 231.60 & $703.37 e$ & 1077.50 & 39.50 \\
\hline $\mathrm{B}_{2} \times \mathrm{W}_{0}$ & 31.35 & 6.60 & 10.23a & 4.13 & 22.61 & $3.88 b c$ & 227.97 & $526.48 \mathrm{ijk}$ & 828.00 & 38.87 \\
\hline $\mathrm{B}_{2} \times \mathrm{W}_{1}$ & 33.48 & 6.67 & 9.73abc & 4.53 & 23.61 & $4.26 b$ & 229.60 & $607.32 \mathrm{fg}$ & 997.00 & 37.89 \\
\hline $\mathrm{B}_{2} \times \mathrm{W}_{2}$ & 34.24 & 7.13 & $9.13 a-d$ & 4.20 & 20.29 & $3.34 \mathrm{~d}-\mathrm{g}$ & 232.67 & $690.98 \mathrm{e}$ & 1119.75 & 38.17 \\
\hline $\mathrm{B}_{2} \times \mathrm{W}_{3}$ & 38.47 & 7.30 & $9.17 a-d$ & 3.87 & 20.93 & $2.9 f-i$ & 232.43 & $760.12 \mathrm{~cd}$ & 1247.50 & 37.89 \\
\hline $\mathrm{B}_{3} \times \mathrm{W}_{0}$ & 31.48 & 4.70 & $7.60 \mathrm{e}$ & 3.00 & 4.89 & $1.61 \mathrm{j}$ & 216.87 & $500.00 \mathrm{jk}$ & 787.50 & 38.86 \\
\hline $\mathrm{B}_{3} \times \mathrm{W}_{1}$ & 32.97 & 5.93 & $9.13 a-d$ & 4.80 & 16.09 & $3.7 c d$ & 222.27 & $730.00 \mathrm{de}$ & 1132.50 & 39.21 \\
\hline $\mathrm{B}_{3} \times \mathrm{W}_{2}$ & 34.80 & 5.80 & $9.33 a-d$ & 4.87 & 18.33 & $3.57 \mathrm{cde}$ & 225.97 & $823.11 b$ & 1272.25 & 39.30 \\
\hline $\mathrm{B}_{3} \times \mathrm{W}_{3}$ & 37.53 & 4.80 & $9.20 a-d$ & 3.87 & 14.25 & $2.72 \mathrm{hi}$ & 226.63 & $886.17 a$ & 1366.25 & 39.38 \\
\hline $\mathrm{B}_{4} \times \mathrm{W}_{0}$ & 27.52 & 4.60 & $8.63 \mathrm{cde}$ & 3.87 & 15.35 & 2.84ghi & 222.03 & 565.00hi & 912.50 & 39.08 \\
\hline $\mathrm{B}_{4} \times \mathrm{W}_{1}$ & 33.71 & 6.57 & 8.37de & 4.20 & 17.96 & $3.09 \mathrm{e}-\mathrm{h}$ & 222.93 & $754.87 d$ & 1216.00 & 38.33 \\
\hline $\mathrm{B}_{4} \times \mathrm{W}_{2}$ & 36.86 & 7.80 & $10.03 a b$ & 5.07 & 29.72 & $5.16 a$ & 222.67 & $796.87 \mathrm{bc}$ & 1231.25 & 39.35 \\
\hline $\mathrm{B}_{4} \times \mathrm{W}_{3}$ & 37.62 & 4.67 & $8.77 b-e$ & 4.07 & 15.47 & $2.56 \mathrm{i}$ & 225.57 & $874.17 a$ & 1348.75 & 39.33 \\
\hline CV (\%) & 6.54 & 5.45 & 11.54 & 7.27 & 12.25 & 6.22 & 3.02 & 5.69 & 7.45 & 8.85 \\
\hline Level of sig. & NS & NS & $* *$ & NS & NS & $* *$ & NS & $* *$ & NS & NS \\
\hline
\end{tabular}

In a column the figure bearing same letter(s) or without letter is identical and those having dissimilar letter differed significantly. ${ }^{*}=$ Significant at $5 \%$ level, ${ }^{* *}=$ Significant at $1 \%$ level, NS= Non significant; $\mathrm{B}_{0}=$ no biofertilizer, $\mathrm{B}_{1}=1.0 \mathrm{~kg} \mathrm{ha}^{-1}$ biofertilizer, $\mathrm{B}_{2}=1.5 \mathrm{~kg}$ ha ${ }^{-1}$ biofertilizer, $\mathrm{B}_{3}=2.0 \mathrm{~kg}$ ha ${ }^{-1}$

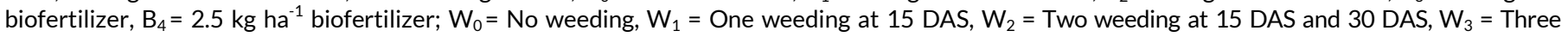
weeding at 15 DAS, 30 DAS and 45DAS. 
Conclusion

The results obtained from this experiment indicated that yield attributes differed with different levels of biofertilizer and weeding regimes. The highest yield was produced from seed inoculated with biofertilizer @ $2 \mathrm{Kg} \mathrm{ha}^{-1}$ with three weeding followed by biofertilizer @ $2.5 \mathrm{Kg} \mathrm{ha}^{-1}$ with three weeding. Biofertilizer @ $2 \mathrm{Kg} \mathrm{ha}^{-1}$ increased the yield of bushbean which is beneficial than $2.5 \mathrm{Kg} \mathrm{ha}^{-1}$ and reduced the fertilizer loss and three weeding was found the best. Therefore, it can be concluded that with manipulation of biofertilizer dose and weeding regimes, there is an ample potential to cultivate Bush bean in Bangladesh context.

\section{ACKNOWLEDGEMENT}

The authors are thankful to the Ministry of Science and Technology (MOST), Bangladesh for financial (Project no: 39.00.0000.09.02.069.16-17/11/45/BS-265) support to conduct the present research successfully.

Open Access: This is open access article distributed under the terms of the Creative Commons Attribution License, which permits unrestricted use, distribution, and reproduction in any medium, provided the original author(s) and the source are credited.

\section{REFERENCES}

Ali, M. and Kushwaha, B.I. (1987). Cultivation of Rabi rajmash in plains. Indian Farming, 37(2): 20-23, http://dpd.gov.in/ Rajmash.pdf

Anjum, M. S., Ahmed, Z. I., and Rauf, C.A. (2006). Effect of Rhizobium inoculation and nitrogen fertilizer on yield and yield components of mungbean. International Journal of Agriculture and Biology, 8(2):238-240, http:// www.fspublishers.org/published_papers/44385_.pdf

BARI, Bangladesh Agricultural Research Institute (1985). Effect of time of weeding and plant density on the growth and yield of mung bean (Kharif). Agronomy Division Bangladesh Agricultural Research Inststitute. Joydebpur, Gazipur. pp. 12-18.

BARI, Bangladesh Agricultural Research Institute (2014). Krishi Prajikti Hatboi. Bangladesh Agricultural Research Institute. Joydebpur, Gazipur. pp. 483-487.

Bhuiya, Z.H., Hoque, M.S. and Mian, M.H. (1984). Field trial at BAU farm on the effect of Rhizobium inoculation on mungbean. First annual report on BNF under irrigated and rainfed condition. pp. 11-14.

Chanda, M.C., Satter, M.A., Solaiman, A.R.M. and Podder, A.K. (1991). Effect of Rhizobium inoculation on mungbean varieties as affected by chemical fertilizers. International Botany Conference 10-12 January, 1991. Dhaka, Bangladesh, pp. 9, http://agris.fao.org/agris-search/ search.do?recordID=BD9125067

Chouwdhury, M.M.U., Ullah, M.H. and Mahmmud, Z.U. (2000). Dry matter production in mungbean (Vigna radiata $\mathrm{L}$.
Wilezek) as influenced by Bradyrhizobium inoculation and phosphorus application. Legume Research, 23(1): 15-20, https://arccjournals.com/journal/legume-researchan-international-journal/ARCC4054

Esmaeilzadeh, S. and Aminpanah, H. (2015). Effects of planting date and spatial arrangement on common bean (Phaseolus vulgaris) yield under weed-free and weedy conditions. Planta Daninha, 33(3): 425-432, http://www.scielo.br/pdf/ $\mathrm{pd} / \mathrm{v33n3/0100-8358-pd-33-03-00425.pdf}$

FAO (2014). UN Food and Agriculture Organization. http:// faostat.fao.org/beta/en/\#data/QC

Gicharu, G.K., Gitonga, N.M., Hamadi, B., Cheruiyot, R.C. and Maingi, J.M. (2013). Variation in nitrogen fixation among three Bush Bean cultivars grown in Kenya when inoculated with three Rhizobia Strains. Greener Journal of Agricultural Sciences, 3(11): 748-754, http://ir-library.ku.ac.ke/ handle/123456789/13176

Gomez, A.K. and Gomez, A.A. (1984). Statistical Procedures for Agricultural Research. Second Edition. John Wiley and Sons, New York, U.S.A. pp. 680, https://pdf.usaid.gov/ pdf_docs/PNAAR208.pdf

Graham, P. H. (1981). Some problems of nodulation and symbiotic fixation in Phaseolus vulgaris. Field Crops Research, 4:93I02, https://doi.org/10.1016/0378-4290(81)90060-5

Hussein, K. A. and Joo, J. H. (2011). Effects of several effective microorganisms (EM) on the growth of Chinese cabbage (Brassica rapa). Korean Journal of Soil Science and Fertilizer, 44 (4): 565-574, http://agris.fao.org/agris-search/search.do? recordID=KR2012003647

Islam, M.K., Islam, S.M.A., Harun-or-Rashid M, Hossain A.F.M.G.F. and Alom, M.M. (2006). Effect of bio-fertilizer and plant growth regulators on growth of summer mungbean. International Journal of Botany, 2(1): 36-41, https:// scialert.net/fulltextmobile/?doi=ijb.2006.36.41

Lawn, R. J. and Ahn, C.S. (1985). Mungbean. p. 584-622. In R. J. Summerfield and E. H. Roberts (ed.) Grain Legume Crops, Collins, U.K.

Madrid, M.T. and Vega, M.R. (1971). Duration of weeds control and weed competition and the effect on yield of mungbean (Phaseolus aureus L.). Philippine Agriculture, 55: 216-220.

Malik, M. M. R., Akhtar, M. J., Ahmad, I. and Khalid, M. (2014). Synergistic use of rhizobium, compost and nitrogen to improve growth and yield of mungbean (Vigna radiata). Pakistan Journal of Agricultural Sciences, 51: 393-398.

Mia, M.A. and Shamsuddin, Z.H. (2010). Rhizobium as a crop enhancer and biofertilizer for increased cereal production. African Journal of Biotechnology, 9(37): 6001-6009, https:// www.ajol.info/index.php/ajb/article/view/92165

Mmbaga, G.W., Mtei, K.M. and Ndakidemi, P.A. (2014). Extrapolations on the use of rhizobium inoculants supplemented with phosphorus and potassium on growth and nutrition of legumes. Agricultural Sciences, 5:1207-1226, https:// www.scirp.org/ journal/ Paper Information. aspx? Paper ID=51023

Mulas, D., García-Fraile, P., Carro, L., Ramírez-Bahena, M.H., 
Casquero, P., Velázquez, E. and González-Andrés, F. (2011). Distribution and efficiency of Rhizobium leguminosarum strains nodulating Phaseolus vulgaris in Northern Spanish soils: Selection of native strains that replace conventional $N$ fertilization. Soil Biology and Biochemistry, 43(11): 22832293, https://doi.org/10.1016/j.soilbio.2011.07.018

Pramanik, J. K., Sayedul Haque Chowdhury, A.K.M. and Jamil Uddin, F.M. (2014). Effect of biofertilizer and weeding on the growth characters and seed yield of summer mungbean. Journal of Environmental Science and Natural Resources, 7(1): 87-92, https://www.banglajol.info/index.php/JESNR/ article/view/22150

Pramanik, J.K., Chowdhury, A.K.M.S.H., and Jamil Uddin, F.M. (2015). Bio-fertilizer and weeding regimes effect on yield and yield attributes of summer mungbean. International Journal of Sustainable Crop Production, 10(1): 26-32, http:// ggfjournals.com/content/papers/MIN-485
Rashid, M.M. (1993). Sabji Biggan (in Bengali), $1^{\text {st }}$ ed. Bangla Academy, Bangladesh. pp. 387-390.

Shanmugavelu, K.G. (1989). Production technology of vegetable crops. Oxford and IBH Publishing Co. Pvt. Ltd., New Delhi. pp. 446-461, https://www.cabdirect.org/cabdirect/ abstract/19900397605

Uddin, F.M., Jamil, Kashem, Islam, M.A., Mominul, A.K.M. and Sarkar, M.A.R. (2017). Optimizing sowing date for French bean varieties under Bangladesh condition. Annual Research \& Review in Biology, 21(3): 1-7, http://www. sciencedomain.org/review-history/22398

Uddin, F.M.J., Sarkar, M.A.R. and Rashid, M.H. (2013). Level of phosphorus and varietal effect with planting time on seed yield and yield contributing characters of mungbean. Bangladesh Research Publications Journal, 9(2): 141-146, http://bd research publications. com/ archive paper/ a085abdc3fdd3368333c4c30f817c602/2 